\title{
Cannabinoid WIN-55,212-2 mesylate inhibits tumor necrosis factor- $\alpha$-induced expression of nitric oxide synthase in dorsal root ganglion neurons
}

\author{
RONG TAN and LIJUN CAO \\ Department of Anesthesiology, The Second Xiangya Hospital, Central South University, Changsha, Hunan 410011, P.R. China
}

Received April 29, 2016; Accepted January 19, 2018

DOI: $10.3892 / \mathrm{ijmm} .2018 .3687$

\begin{abstract}
Tumor necrosis factor- $\alpha(\mathrm{TNF}-\alpha)$ is an established pain modulator in the peripheral nervous system. Elevated levels of TNF- $\alpha$ in dorsal root ganglion (DRG) neurons reportedly is critical for neuropathic pain processing. It has been shown that the production of nitric oxide, a key player in the development and maintenance of nociception, depends on the expression of nitric oxide synthases (NOSs) and their activities. Accumulating evidence also supports an important role of cannabinoids in modulating neuropathic pain. In this study, we explored the effects and the underlying mechanisms of crosstalk between TNF- $\alpha$ and cannabinoid on the expression/activity of NOS in DRG neurons. With or without knockdown of p38 mitogen-activated protein kinase (MAPK), DRG neurons were treated with TNF- $\alpha$ in the presence or absence of synthetic cannabinoid WIN-55,212-2 mesylate (WIN-55) and selective cannabinoid receptor (CB) antagonists. TNF- $\alpha$ significantly increased the NOS activity as well as the mRNA stability and expression of neuronal NOS (nNOS) in DRG neurons; this was abolished by inhibiting p38 MAPK signaling. WIN-55 inhibited TNF- $\alpha$-induced p38 MAPK activity as well as TNF- $\alpha$-induced increase of mRNA stability and expression/activity of nNOS; the inhibitory effect of WIN-55 was blocked by a selective CB2 antagonist. Our findings suggest that TNF- $\alpha$ induces the expression/activity of nNOS in DRG neurons by increasing its mRNA stability by a p38 MAPK-dependent mechanism; WIN-55 inhibits this effect of TNF- $\alpha$ by inhibiting p38 MAPK via CB2. By linking the functions of TNF- $\alpha$, NOS and cannabinoid in DRG neurons, this study adds new insights into the molecular
\end{abstract}

Correspondence to: Dr Lijun Cao, Department of Anesthesiology, The Second Xiangya Hospital, Central South University, 86 Middle Renmin Road, Changsha, Hunan 410011, P.R. China

E-mail: hivit1103@163.com

Key words: cannabinoid, WIN-55,212-2 mesylate, tumor necrosis factor- $\alpha$, nitric oxide synthase, p38 mitogen-activated protein kinase, cannabinoid receptor type 2 , dorsal root ganglion neuron, mRNA stability mechanisms underlying the pharmacologic effects of cannabinoids on neuropathic pain as well as into the pathophysiology of neuropathic pain.

\section{Introduction}

Affecting $~ 12-13 \%$ of the general population, neuropathic pain due to disease or lesions affecting the somatosensory nervous system is a prevalent condition, for which currently there is no effective treatment $(1,2)$. It is a condition that is often refractory to opioids or requires larger doses that possess unacceptable side effects (3). Therefore, it is important to understand the pathophysiology of neuropathic pain and the underlying molecular mechanisms, which will facilitate development of novel therapies.

Neuropathic pain is closely associated with hyperresponsiveness of sensory neurons in the dorsal root ganglion (DRG) and the spinal cord dorsal horn (4). Previous studies have shown that elevated levels of proinflammatory cytokine tumor necrosis factor- $\alpha$ (TNF- $\alpha)$ in DRG neurons is critical for neuropathic pain processing (5). TNF- $\alpha$ antibodies have been shown to reduce pain-associated behaviors in animal models of neuropathic pain (5), suggesting a key role of TNF- $\alpha$ in neuropathic pain and nociception. TNF- $\alpha$ receptor TNFR1 reportedly is expressed on most cells as a major mediator of the cytotoxicity of TNF- $\alpha(6)$.

Nitric oxide (NO) is involved in sensitization of sensory neurons after noxious stimuli and is linked with the development and maintenance of nociception $(7,8)$. The production of NO mainly depends on the expression of nitric oxide synthases (NOSs) and their activities (7). Neuronal NOS (nNOS) is localized in neurons and is dynamically regulated after peripheral inflammation, while inducible NOS (iNOS) and endothelial NOS (eNOS) is normally absent in neural tissues under normal conditions $(7,8)$. Previous studies have shown beneficial effects of selective blockers for NOS in reducing neuropathic pain $(7,8)$.

Accumulating evidence supports a role of cannabinoids in modulating neuropathic pain $(9,10)$. Endogenous cannabinoids and their receptors have been found to be expressed in key areas associated with pain processing and markedly increase in these areas in models of chronic pain (11-15). Cannabinoids mainly function through cannabinoid receptor type 1 (CB1) 
and CB2 (16). The CB1 receptor is expressed primarily in the nervous system, whereas the $\mathrm{CB} 2$ receptor is mainly expressed in immune cells and is also detectable in brainstem neurons and spinal cord (17). Recent report has shown that both CB1 and CB2 are expressed in DRG neurons (18). Previous studies have shown significant antinociceptive effects of cannabinoid receptor agonists in animal models of spontaneous, inflammatory and neuropathic pain (19).

In the present study, we explored the effects and the underlying mechanisms of crosstalk between TNF- $\alpha$ and cannabinoid on the expression/activity of NOS in DRG neurons.

\section{Materials and methods}

Cell culture and treatment. Rat DRG neurons (cat. no. R-DRG-505) and primary neuron medium (cat. no. CC-3256) were purchased from Lonza Inc. (Houston, TX, USA). The cells were suspensions of high quality sensory neurons prepared by standardized methods and were ready for immediate culture. The cells were treated with recombinant human TNF- $\alpha$ (cat. no. T6674; Sigma-Aldrich, Beijing, China) in different concentrations $(5,10,20,30$ and $40 \mathrm{ng} / \mathrm{ml})$ for 1 , $5,10,15,20$ and $25 \mathrm{~h}$. For kinase inhibitor or TNFR1 inhibitor SPD304 (cat. no. S1697; Sigma-Aldrich) treatment, DRG neurons were pretreated with a kinase inhibitor or SPD304 for $30 \mathrm{~min}$, and then incubated with TNF- $\alpha(40 \mathrm{ng} / \mathrm{ml})$ and the kinase inhibitor or SPD304 for $25 \mathrm{~h}$. For the synthetic cannabinoid WIN-55,212-2 mesylate (WIN-55) (cat. no. 1038; Tocris Bioscience, Bristol, UK) treatment, DRG neurons were treated with WIN-55 $(100,200,300$ and $400 \mathrm{ng} / \mathrm{ml})$ in the presence of TNF- $\alpha(40 \mathrm{ng} / \mathrm{ml})$ for $1,5,10,15,20$ and $25 \mathrm{~h}$ with or without selective CB1 antagonist MJ15 (cat. no. 4063) or selective CB2 antagonist JTE907 (cat.no. 2479) (both from Tocris Bioscience). For p38 mitogen-activated protein kinase (MAPK) knockdown, p38 MAPK siRNA (cat. no. sc-156091; Santa Cruz Biotechnology, Inc., Dallas, TX, USA) was transfected into DRG neurons using Lipofectamine 3000 transfection reagent (cat. no. L3000008; Thermo Fisher Scientific, Beijing, China) by the manufacturer's protocol; the cells were subjected to subsequent experiments $24 \mathrm{~h}$ after the transfection.

NOS activity assay. The NOS activity was measured with a NOS activity assay kit (cat. no. KA1345; Abnova, Taipei, Taiwan) according to the manufacturer's protocol. This assay is based on the conversion of $\left[{ }^{14} \mathrm{C}\right]-\mathrm{L}$-arginine to $\left[{ }^{14} \mathrm{C}\right]-\mathrm{L}$ citrulline by NOS. NOS activity was calculated as follows: NOS activity $(\mathrm{pmol} / \mu \mathrm{g} / \mathrm{min})=\left[{ }^{14} \mathrm{C}\right]$-radioactivity in the flow-through (CPM)/total protein amount $(\mu \mathrm{g}) /$ specific radioactivity of $\left[{ }^{14} \mathrm{C}\right]-\mathrm{L}$-arginine $(\mathrm{Bq} / \mathrm{pmol})$. Each experiment was repeated for three independent times in duplicates.

Real-time quantitative RT-PCR and measurement of nNOS $m R N A$ stability. RNA was prepared from cells using TRIzol reagent (Thermo Fisher Scientific) followed by purification with TURBO DNA-free system (Ambion, Austin, TX, USA). cDNA was synthesized using SuperScript II reverse transcriptase and random hexamer primers (both from Thermo Fisher Scientific). RT-qPCR was performed using an ABI-PRISM 7700 Sequence detection system (Applied Biosystems; Thermo Fisher Scientific) and the fluorescent dye SYBR-Green Master Mix (Thermo Fisher Scientific) as described by the manufacturer. The primers used were as follows: forward, 5'-CACGTGGTCCTCATTC TGAG-3' and reverse, 5'-CAGATCGACGGCTTTGGT-3' for nNOS; forward, 5'-TCGTACTTGGGATGCTCCATGG-3' and reverse, 5'-TCCTGCAGGCTCACGGTCAA-3' for iNOS; forward, 5'-CCCTGTAATTGGAATGAGTCCAC-3' and reverse, 5'-GCTGGAATTACCGCGGCT-3' for 18S rRNA. The PCR amplification condition was: $20 \mathrm{sec}$ at $95^{\circ} \mathrm{C}$ followed by 40 cycles of $3 \mathrm{sec}$ at $95^{\circ} \mathrm{C}$ and $30 \mathrm{sec}$ at $60^{\circ} \mathrm{C}$. Relative quantification of the nNOS or iNOS level was determined using the $2^{-\Delta \Delta C t}$ method (20) and normalized against that of 18S rRNA in the same sample. Each experiment was repeated for three independent times in duplicates. For measurement of the nNOS mRNA stability, DRG neurons were treated with or without TNF- $\alpha$ in the presence or absence of WIN-55, p38 MAPKsiRNA or scramble control siRNA (Scr) for $25 \mathrm{~h}$. Then the cells were cultured in media containing transcription inhibitor actinomycin D $(1 \mathrm{mg} / \mathrm{ml})$ for 1,2 and $4 \mathrm{~h}$. The mRNA levels of nNOS were determined with real-time quantitative RT-PCR at 1,2 and $4 \mathrm{~h}$ of actinomycin D treatment.

Western blot analysis. Whole cell lysates were extracted by incubating the DRG neurons with lysis buffer $(50 \mathrm{mM}$ Tris/HCl $\mathrm{pH} 7.2,150 \mathrm{mM} \mathrm{NaCl}, 1 \%$ (v/v) Triton X-100, $1 \mathrm{mM}$ sodium orthovanadate, $50 \mathrm{mM}$ sodium pyrophosphate, $100 \mathrm{mM}$ sodium fluoride, $0.01 \%(\mathrm{v} / \mathrm{v})$ aprotinin, $4 \mu \mathrm{g} / \mathrm{ml}$ pepstatin A, $10 \mu \mathrm{g} / \mathrm{ml}$ leupeptin and $1 \mathrm{mM}$ phenylmethanesulfonyl fluoride; all purchased from Sigma-Aldrich) on ice for $30 \mathrm{~min}$ and removing cell debris by centrifugation at 2,000 $\mathrm{x}$ g for $15 \mathrm{~min}$ at $4^{\circ} \mathrm{C}$. Equal amount of proteins for each sample were separated by $10 \%$ sodium dodecyl sulfate (SDS)-polyacrylamide gel and blotted onto a polyvinylidene difluoride microporous membrane (Millipore, Billerica, MA, USA). The membranes were blocked with 5\% skim milk powder in TBS-T for $2 \mathrm{~h}$ and incubated for $1 \mathrm{~h}$ with a 1:1,000 dilution of rabbit antirat nNOS (NOS1) polyclonal antibody (cat. no. sc-648) or mouse anti-rabbit glyceraldehyde 3-phosphate dehydrogenase (GAPDH) monoclonal antibody (cat. no. sc-32233), and then washed and revealed using bovine anti-rabbit (cat. no. sc-2370) or bovine anti-mouse (cat. no. sc-2371) (all from Santa Cruz Biotechnology, Inc.) secondary antibody (1:5,000, $1 \mathrm{~h})$. Peroxidase was revealed with an ECL kit purchased from GE Healthcare (Shanghai, China). Three independent experiments were performed.

p38 MAPK activity assay. p38 MAPK activity was measured with a p38 MAPK assay kit (cat. no. 9820; Cell Signaling Technology, Beverly, MA, USA) according to the manufacturer's protocol (21). Briefly, cell lysates were sonicated and centrifuged at $15,000 \mathrm{rpm}$ for $10 \mathrm{~min}$ at $4^{\circ} \mathrm{C}$. The supernatant containing equivalent amounts of protein $(200 \mu \mathrm{g})$ was incubated by gentle rocking with $20 \mu 1$ of immobilized phospho-p38-MAPK monoclonal antibody for $16 \mathrm{~h}$ at $4{ }^{\circ} \mathrm{C}$. The immunoprecipitates were washed twice with the lysing buffer and pelleted by centrifugation. The p38 MAPK assay was carried out using ATF2 fusion protein $(2 \mu \mathrm{g})$ as a substrate in the presence of $200 \mu \mathrm{M}$ ATP and 1X kinase buffer following the manufacturer's recommendations. Samples were resolved on a $12 \%$ SDS-PAGE gel and visualized by autoradiography. 


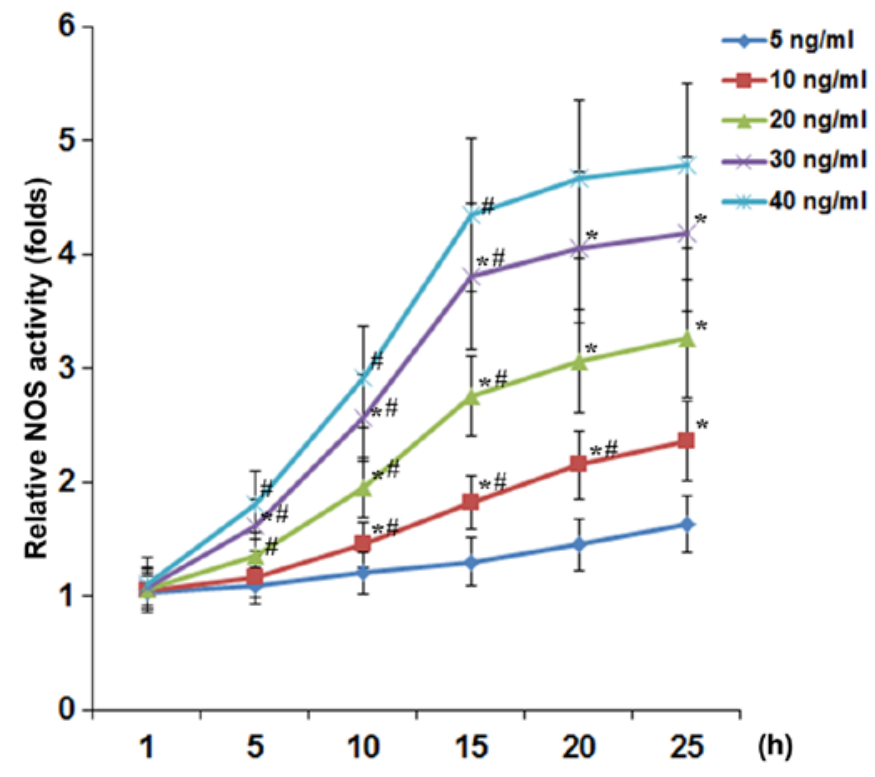

Figure 1. Nitric oxide synthases (NOS) activity in dorsal root ganglion (DRG) neurons under tumor necrosis factor- $\alpha$ (TNF- $\alpha$ ) treatment. DRG neurons were treated with TNF- $\alpha(5,10,20,30$ and $40 \mathrm{ng} / \mathrm{ml})$ for $1,5,10,15$, 20 and $25 \mathrm{~h}$. The NOS activity was measured and expressed as fold-changes to that of untreated cells (designated as 1 ). ${ }^{*} \mathrm{p}<0.05$ vs. immediate lower concentration; ${ }^{*} \mathrm{p}<0.05$ vs. immediate previous time-point.

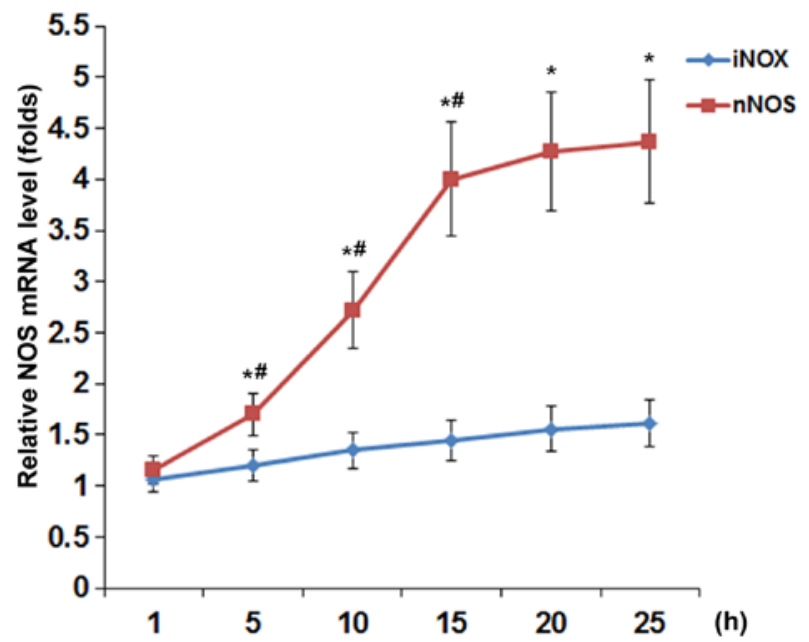

Figure 2. Nitric oxide synthases (NOS) mRNA levels in dorsal root ganglion (DRG) neurons under tumor necrosis factor- $\alpha$ (TNF- $\alpha$ ) treatment. DRG neurons were treated with TNF- $\alpha(40 \mathrm{ng} / \mathrm{ml})$ for $1,5,10,15,20$ and $25 \mathrm{~h}$. The neuronal NOS (nNOS) and inducible NOS (iNOS) mRNA levels were measured and expressed as fold-changes to that of untreated cells (designated as 1$)$. ${ }^{*}<<0.05$ vs. iNOS; ${ }^{\#} \mathrm{p}<0.05$ vs. immediate previous time-point.

Statistical analysis. Statistical analyses were performed with SPSS for Windows 10.0 (SPSS, Inc., Chicago, IL, USA). All values were expressed as mean $\pm \mathrm{SD}$. Comparisons of means among multiple groups were performed with one-way ANOVA followed by post hoc pairwise comparisons using Tukey's tests. $\mathrm{p}<0.05$ was considered statistically significant in this study.

\section{Results}

TNF- $\alpha$-induced expression of $n N O S$ in DRG neurons by a p38 MAPK-dependent mechanism. To examine the effect

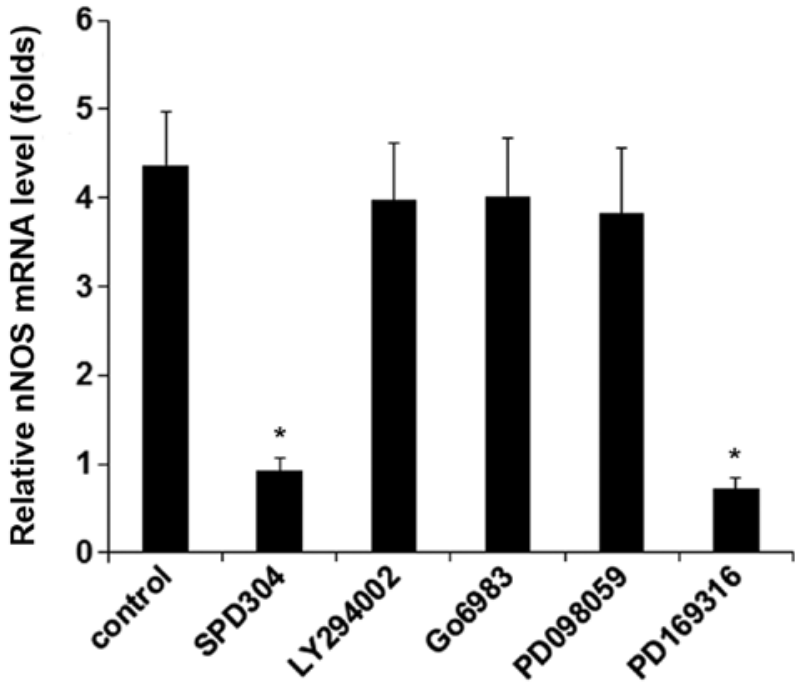

Figure 3. Neuronal nitric oxide synthase (nNOS) mRNA levels in dorsal root ganglion (DRG) neurons under tumor necrosis factor- $\alpha$ (TNF- $\alpha$ ) treatment with or without kinase inhibitors. DRG neurons were respectively pretreated with selective inhibitor for phosphatidylinositol-3 kinase (LY294002; $50 \mu \mathrm{M}$ ), protein kinase C (Go6983; $250 \mathrm{nM}$ ), MAPK (PD098059; $25 \mu \mathrm{M}$ ) and p38 MAPK (PD169316; $25 \mu \mathrm{M})$, or selective TNF- $\alpha$ receptor 1 inhibitor SPD304 $(50 \mu \mathrm{M})$ for $30 \mathrm{~min}$, and then incubated with TNF- $\alpha(40 \mathrm{ng} / \mathrm{ml})$ and the kinase inhibitor or SPD304 for $25 \mathrm{~h}$. DRG neurons treated with TNF- $\alpha$ only were used as a control. The mRNA levels of nNOS were measured and expressed as fold-changes to those of untreated cells (designated as 1). * $\mathrm{p}<0.05$ vs. control.

of TNF- $\alpha$ on the expression and activity of NOS in DRG neurons, we treated DRG neurons with TNF- $\alpha(5,10,20,30$ and $40 \mathrm{ng} / \mathrm{ml}$ ) for 1, 5, 10, 15, 20 and $25 \mathrm{~h}$. As show in Fig. 1, TNF- $\alpha$ concentration- and time-dependently increased the NOS activity in DRG neurons. At TNF- $\alpha$ concentrations $\geq 20 \mathrm{ng} / \mathrm{ml}$, the inducing effect of TNF- $\alpha$ on the NOS activity reached a plateau after $15 \mathrm{~h}$ of treatment. As shown in Fig. 2, TNF- $\alpha$ (40 ng/ml) time-dependently increased the mRNA levels of nNOS but not iNOS or eNOS (barely detectable; data not shown) in DRG neurons, with the nNOS mRNA level showing similar data trend as the NOS activity in Fig. 1.

In DRG neurons treated with TNF- $\alpha$ (40 ng/ml for $25 \mathrm{~h}$ ), inhibiting TNFR1 by SPD304 or inhibiting p38 MAPK by PD169316 completely abolished TNF- $\alpha$-induced expression of nNOS, while inhibition of phosphatidylinositol-3 kinase, protein kinase $\mathrm{C}$, and mitogen-activated protein kinase showed no significant effect (Fig. 3). The results suggested that TNF- $\alpha$ induced the expression/activity of nNOS in DRG neurons via TNFR1 by a $\mathrm{p} 38$ MAPK-dependent mechanism. We next knocked down p38 MAPK in DRG neurons. As shown in Fig. 4A, the constitutive expression of p38 MAPK was knocked down by specific siRNA by $\sim 75 \%$ compared with the controls. Western blot analyses confirmed that TNF- $\alpha$ (40 $\mathrm{ng} / \mathrm{ml})$ time-dependently increased the protein levels of nNOS in DRG neurons; this effect was largely abolished by p38 MAPK-siRNA (Fig. 4B).

WIN-55 inhibits TNF- $\alpha$-induced expression of $n N O S$ via $C B 2$ in DRG neurons. As shown in Fig. 5, in DRG neurons treated with TNF- $\alpha(40 \mathrm{ng} / \mathrm{ml})$, synthetic cannabinoid WIN-55 (100, 200, 300 and $400 \mathrm{ng} / \mathrm{ml}$ ) concentration- and time-dependently abolished TNF- $\alpha$-induced expression of nNOS, with WIN-55 
A
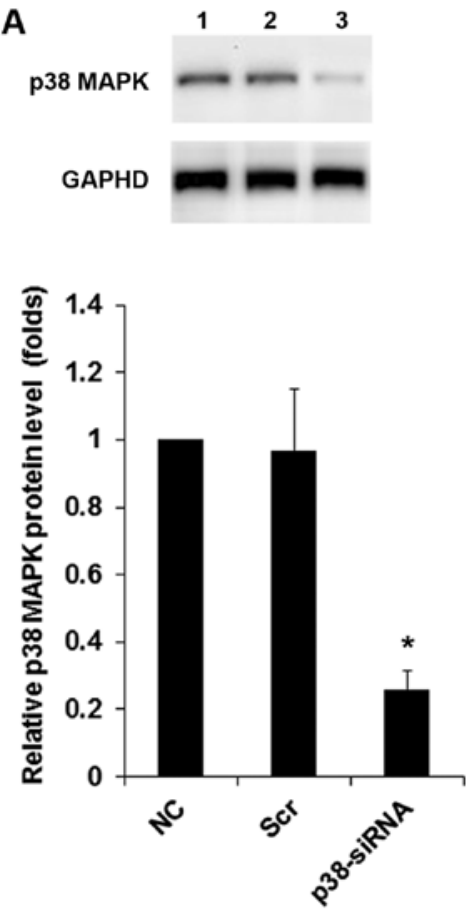

B
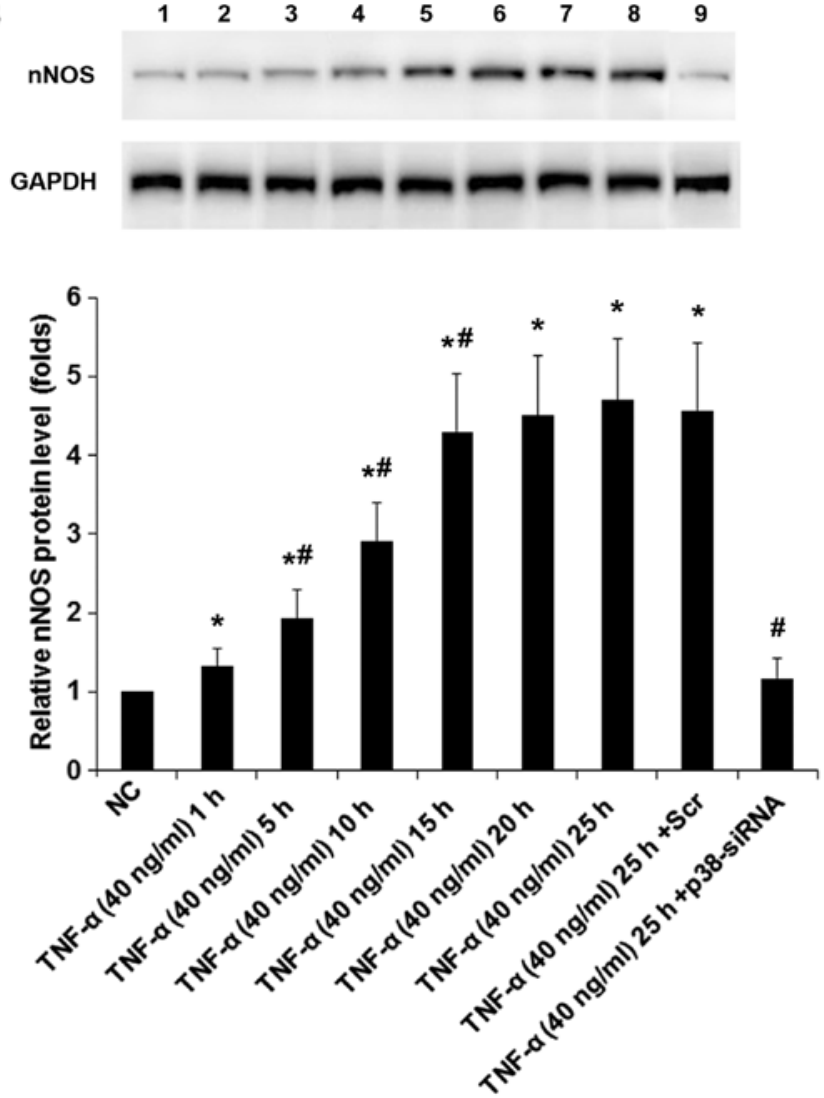

Figure 4. Neuronal nitric oxide synthase (nNOS) protein levels in dorsal root ganglion (DRG) neurons under tumor necrosis factor- $\alpha$ (TNF- $\alpha$ ) treatment with or without p38 MAPK knockdown. (A) DRG neurons were transfected with p38 MAPK (p38)-siRNA (lane 3), using untreated cells (NC; lane 1) and cells transfected with scramble control siRNA (Scr; lane 2) as controls. The protein levels of p38 MAPK were determined with western blot analyses. Glyceraldehyde 3-phosphate dehydrogenase (GAPDH) was used as a loading control. Density of the p38 MAPK blot was normalized against that of the GAPDH blot to obtain a relative blot density, which was expressed as fold changes to that of NC (designated as 1 ). "p<0.05 vs. NC. (B) DRG neurons were treated with TNF- $\alpha$ ( $40 \mathrm{ng} / \mathrm{ml}$ ) for 1 (lane 2), 5 (lane 3), 10 (lane 4), 15 (lane 5), 20 (lane 6) and 25 (lane 7) hours with or without transfection of scramble control siRNA (Scr; lane 8) or p38 MAPK (p38)-siRNA (lane 9). Untreated cells (NC; lane 1) were used as a control. The protein levels of nNOS were determined with western blot analyses. GAPDH was used as a loading control. Density of the nNOS blot was normalized against that of the GAPDH blot to obtain a relative blot density, which was expressed as fold changes to that of $\mathrm{NC}$ (designated as 1 ). ${ }^{*} \mathrm{p}<0.05 \mathrm{vs.} \mathrm{NC} ;{ }^{*} \mathrm{p}<0.05$ vs. immediate previous experimental group.

at $400 \mathrm{ng} / \mathrm{ml}$ completely abolishing the effect of TNF- $\alpha$. In DRG neurons treated with TNF- $\alpha(40 \mathrm{ng} / \mathrm{ml})$ in the presence of WIN-55 (400 ng/ml), selective CB2 antagonist JTE907 but not selective CB1 antagonist MJ15 largely blocked the inhibitory effect of WIN-55 on TNF- $\alpha$-induced expression of nNOS (Fig. 6A) and NOS activity (Fig. 6B).

WIN-55 inhibits TNF- $\alpha$-induced increase of $n N O S$ mRNA stability in DRG neurons. The above findings suggested that TNF- $\alpha$ induced the expression of nNOS in DRG neurons by a p38 MAPK-dependent mechanism; WIN-55 effectively inhibited this effect mainly via CB2. Since TNF- $\alpha$ and WIN-55 showed no significant effect on the nNOS gene promoter (data not shown), we next examined the effect of TNF- $\alpha$ and WIN-55 on the stability of nNOS mRNA. DRG neurons were treated with TNF- $\alpha(5,20$ and $40 \mathrm{ng} / \mathrm{ml})$ for $25 \mathrm{~h}$ in the presence of WIN-55 (100 or $400 \mathrm{nM})$. Then the cells were cultured in media containing transcription inhibitor actinomycin D for 1,2 and $4 \mathrm{~h}$. The mRNA levels of nNOS were determined at 1,2 and $4 \mathrm{~h}$ of actinomycin D treatment and expressed as percentages of that immediately before actinomycin D treatment in each experimental group. As shown in Fig. 7, the relative nNOS mRNA levels in the control cells at 1,2 and $4 \mathrm{~h}$ of actinomycin D treatment were
71,32 and $9 \%$, respectively. TNF- $\alpha$ concentration-dependently elevated the relative nNOS mRNA levels, up to 99,81 and $46 \%$ by $40 \mathrm{ng} / \mathrm{ml}$ of TNF- $\alpha$ at 1,2 and $4 \mathrm{~h}$ of actinomycin D treatment, respectively (Fig. 7). On the other hand, WIN-55 concentrationdependently inhibited the effect of TNF- $\alpha$. Particularly, in the presence of $40 \mathrm{ng} / \mathrm{ml}$ of TNF- $\alpha$, WIN-55 at $400 \mathrm{nM}$ decreased the relative nNOS mRNA levels to 78,38 and $11 \%$ at 1,2 and $4 \mathrm{~h}$ of actinomycin D treatment, respectively, nearly down to the control level (Fig. 7). In addition, in the presence of $40 \mathrm{ng} / \mathrm{ml}$ of TNF- $\alpha$, siRNA-mediated knockdown of p38 MAPK decreased the relative nNOS mRNA levels down to 81, 41 and $12 \%$ at 1,2 and $4 \mathrm{~h}$ of actinomycin D treatment, respectively (Fig. 7). The findings suggested that TNF- $\alpha$ increased the mRNA stability of nNOS in DRG neurons by a p38 MAPK-dependent mechanism; WIN-55 inhibited this effect.

WIN-55 inhibits TNF- $\alpha$-induced p38 MAPK activity in $D R G$ neurons. To explore potential functional interaction of TNF- $\alpha$ with WIN-55 on p38 MAPK signaling, we measured p38 MAPK activities in DRG neurons treated with TNF- $\alpha$ $(5,20$ and $40 \mathrm{ng} / \mathrm{ml})$ in the presence of WIN-55 (100 or $400 \mathrm{ng} / \mathrm{ml}$ ) for $25 \mathrm{~h}$ with or without MJ15 or JTE907 (Fig. 8). As evidenced by increased levels of phosphorylated ATF2, 


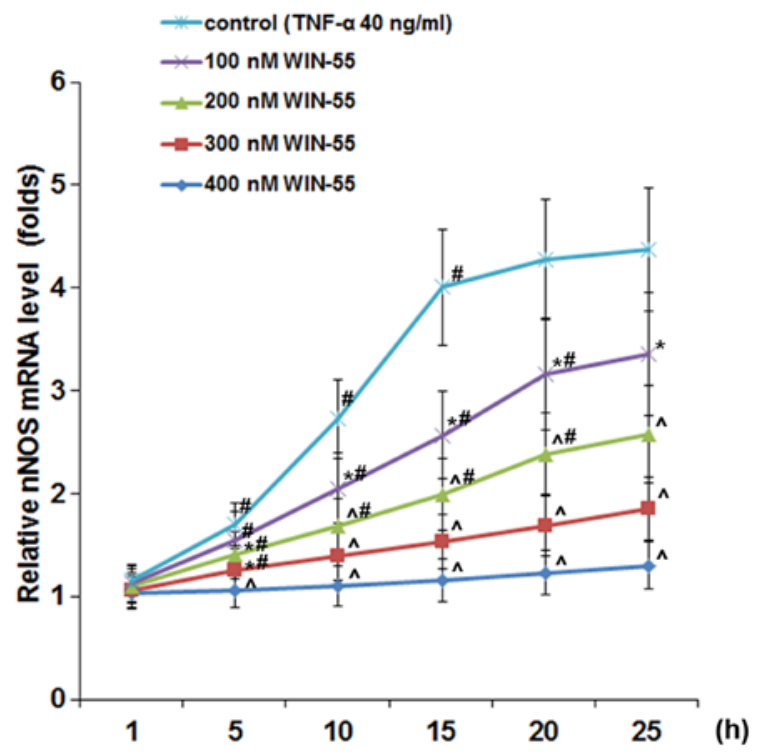

Figure 5. Neuronal nitric oxide synthase (nNOS) mRNA levels in dorsal root ganglion (DRG) neurons under tumor necrosis factor- $\alpha$ (TNF- $\alpha$ ) treatment in the presence of synthetic cannabinoid WIN-55,212-2 mesylate (WIN-55). DRG neurons were treated with TNF- $\alpha(40 \mathrm{ng} / \mathrm{ml})$ in the presence of WIN-55 $(100,200,300$ and $400 \mathrm{ng} / \mathrm{ml})$ for $1,5,10,15,20$ and $25 \mathrm{~h}$. Cells treated with TNF- $\alpha$ only were used as a control. The nNOS mRNA levels was measured and expressed as fold-changes to that of untreated cells (designated as 1$)$. ${ }^{*} \mathrm{p}<0.05$ vs. control; ${ }^{\wedge} \mathrm{p}<0.05$ vs. immediate lower concentration; ${ }^{\#} \mathrm{p}<0.05$ vs. immediate previous time-point.

TNF- $\alpha$ concentration-dependently induced the p38 MAPK activity, which was concentration-dependently decreased by WIN-55; the inhibitory effect of WIN-55 was largely blocked by JTE907 but not MJ15 (Fig. 8). The findings suggested that WIN-55 inhibited TNF- $\alpha$-induced p38 MAPK activity in DRG neurons mainly via CB2.

\section{Discussion}

TNF- $\alpha$ is an established pain modulator in the peripheral nervous system following peripheral nerve injury (5). Elevated levels of TNF- $\alpha$ in DRG neurons reportedly is critical for neuropathic pain processing (5). NO plays an important role in the development and maintenance of nociception (7). It has been shown that the regulation of NO production mainly depends on the expression of NOSs and their activities (7). Previous studies have shown beneficial effects of selective blockers for NOS in reducing neuropathic pain $(7,8)$. Accumulating evidence also support an important role of cannabinoids in the modulation of neuropathic pain $(9,10)$. Significant antinociceptive effects of cannabinoid receptor agonists have been demonstrated in animal models of neuropathic pain (19). In the present study, we provide the first evidence that cannabinoids inhibits TNF- $\alpha$-induced expression/activity of NOS in DRG neurons, thereby linking the functions of TNF- $\alpha$, NOS and cannabinoid in DRG neurons.

We found that TNF- $\alpha$ significantly increased the expression of nNOS but not iNOS and eNOS in DRG neurons via TNFR1. This is in agreement with previous studies showing that only nNOS is increased in mouse spinal cord after inflammation induction (7) and that TNFR1 is expressed on most cells as a major mediator of the cytotoxicity of TNF- $\alpha$ (6). TNF- $\alpha$ in the concentration range of $5-40 \mathrm{ng} / \mathrm{ml}$ increasingly elevated
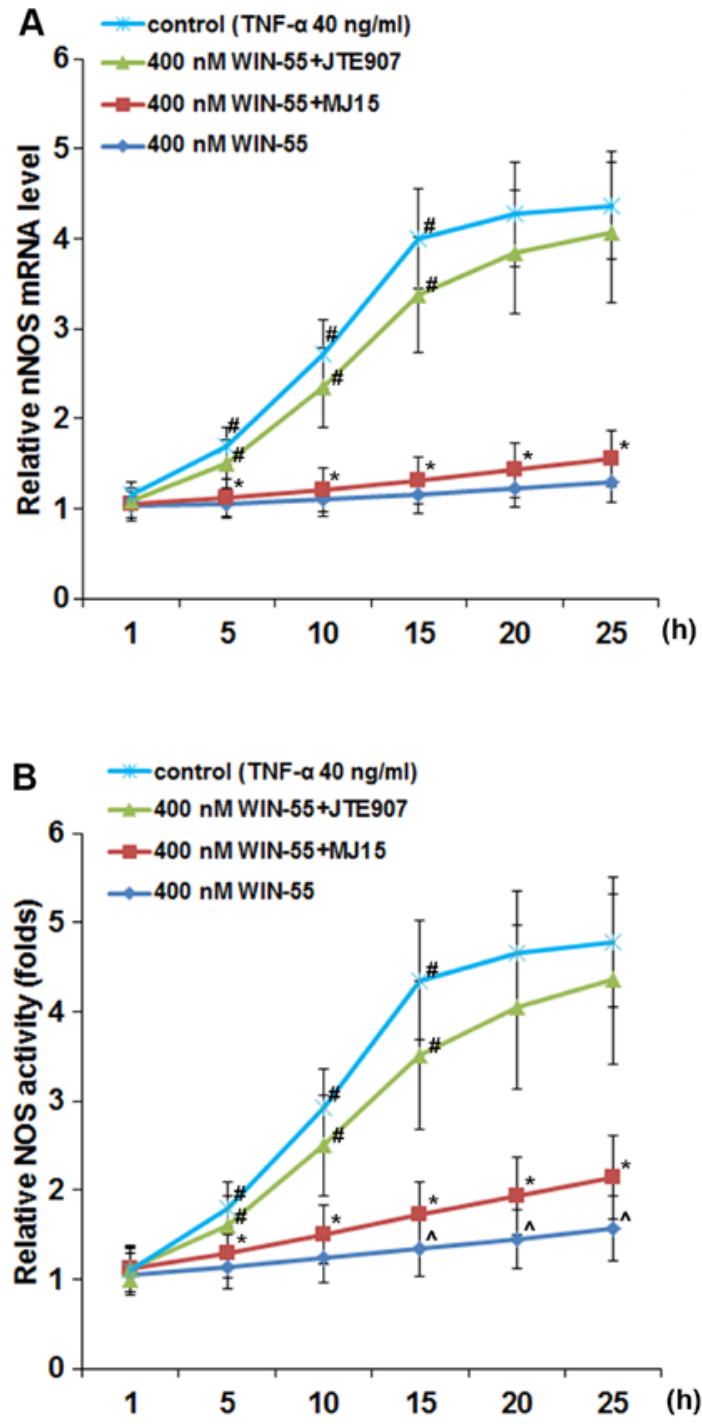

Figure 6. Neuronal nitric oxide synthase (nNOS) mRNA and NOS activity levels in dorsal root ganglion (DRG) neurons under tumor necrosis factor- $\alpha(\mathrm{TNF}-\alpha)$ treatment in the presence of synthetic cannabinoid WIN55,212-2 mesylate (WIN-55) and cannabinoid receptor antagonists. DRG neurons were treated with TNF- $\alpha(40 \mathrm{ng} / \mathrm{ml})$ in the presence of WIN-55 (400 $\mathrm{ng} / \mathrm{ml})$ for $1,5,10,15,20$ and $25 \mathrm{~h}$ with or without selective cannabinoid receptor type $1(\mathrm{CB} 1)$ antagonist $\mathrm{MJ} 15(50 \mu \mathrm{M})$ or selective CB2 antagonist JTE907 $(5 \mu \mathrm{M})$. Cells treated with TNF- $\alpha$ only were used as a control. (A) The nNOS mRNA and (B) the NOS activity levels were measured and expressed as fold-changes to that of untreated cells (designated as 1), respectively. ${ }^{*} \mathrm{p}<0.05$ vs. control and $400 \mathrm{nM}$ WIN-55+JTE907; ${ }^{\wedge} \mathrm{p}<0.05$ vs. $400 \mathrm{nM}$ WIN-55+MJ15; ${ }^{\#} \mathrm{p}<0.05$ vs. immediate previous time-point.

the NOS activity in DRG neurons, until reaching a plateau at $30-40 \mathrm{ng} / \mathrm{ml}$. In addition, at TNF- $\alpha$ concentrations $\geq 20 \mathrm{ng} / \mathrm{ml}$, the inducing effect of TNF- $\alpha$ on the NOS activity reached a plateau after $15 \mathrm{~h}$ of treatment. The findings suggest that TNF- $\alpha$ is an effective fast inducer of the NOS activity, which is in line with its strong and fast induction of nNOS in DRG neurons.

Jia et al showed that TNF- $\alpha$ could phosphorylate and activate $\mathrm{p} 38$ MAPK (22). Wang et al showed that a specific TNF- $\alpha$ inhibitor significantly reduced phosphorylated p38 MAPK levels induced by chronic constriction injury in DRG neurons (23). Xu et al suggested that p38 MAPK activation in DRG neurons is necessary for the initiation and maintenance of neuropathic pain (24). These previous findings suggest that 


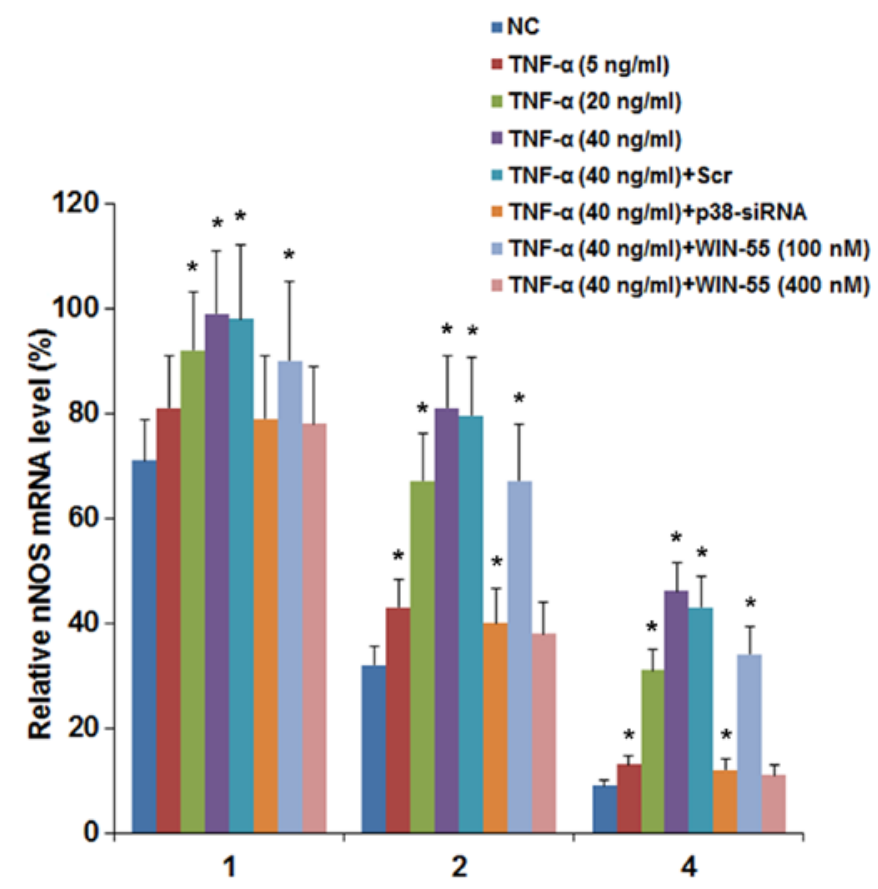

Figure 7. Neuronal nitric oxide synthase (nNOS) mRNA stability in dorsal root ganglion (DRG) neurons under tumor necrosis factor- $\alpha$ (TNF- $\alpha$ ) treatment in the presence of synthetic cannabinoid WIN-55,212-2 mesylate (WIN-55) or p38 MAPK knockdown. DRG neurons with or without transfection of p38 MAPK (p38)-siRNA or scramble control siRNA (Scr) were treated with TNF- $\alpha$ (5, 20 and $40 \mathrm{ng} / \mathrm{ml}$ ) for $25 \mathrm{~h}$ in the presence of WIN-55 (100 or $400 \mathrm{nM}$ ). Then the cells were cultured in media containing transcription inhibitor actinomycin $\mathrm{D}(1 \mathrm{mg} /$ ml) for 1,2 and $4 \mathrm{~h}$. The nNOS mRNA levels were determined at 1,2 and $4 \mathrm{~h}$ of actinomycin D treatment and expressed as percentages of that immediately before actinomycin $\mathrm{D}$ treatment in each experimental group. Cells treated with actinomycin D only were used as a control (NC). " $\mathrm{p}<0.05$ vs. control.

TNF- $\alpha /$ p38 MAPK signaling is an important pathway for neuropathic pain. This is in agreement with our findings that TNF- $\alpha$-induced $\mathrm{p} 38$ MAPK activity is required for TNF- $\alpha$ induced mRNA stability/expression/activity of nNOS, another key player in neuropathic pain. How TNF- $\alpha$-induced activation of p38 MAPK leads to increased mRNA stability of nNOS in DRG neurons will be explored in our future studies.

We found that synthetic cannabinoid WIN-55 potently inhibited TNF- $\alpha$-induced activation of $\mathrm{p} 38$ MAPK largely via CB2, which explains for why WIN-55 inhibited TNF- $\alpha$-p38 MAPK signaling-induced expression of nNOS via CB2 in DRG neurons. This is in agreement with previous studies showing that $\mathrm{CB} 2$ agonists markedly inhibited the activation of p38 MAPK in DRG and effectively controlled neuropathic pain in animal models $(19,25,26)$. Taken together, our findings suggest that cannabinoids are potent inhibitors of the TNF- $\alpha / \mathrm{p} 38$ MAPK/NOS signaling axis in DRG neurons; the effect is mainly mediated via CB2. This adds new insights into the molecular mechanisms underlying the pharmacologic effects of cannabinoids on neuropathic pain.

Endogenous cannabinoids and their receptors have been found to be expressed in key areas associated with pain processing and markedly increase in these areas in models of chronic pain (11-15), suggesting that endogenous cannabinoids are natural modulators of chronic pain. As endogenous cannabinoids may well participate in regulating TNF- $\alpha / \mathrm{p} 38 \mathrm{MAPK} / \mathrm{NOS}$ signaling during the development of neuropathic pain, our findings also

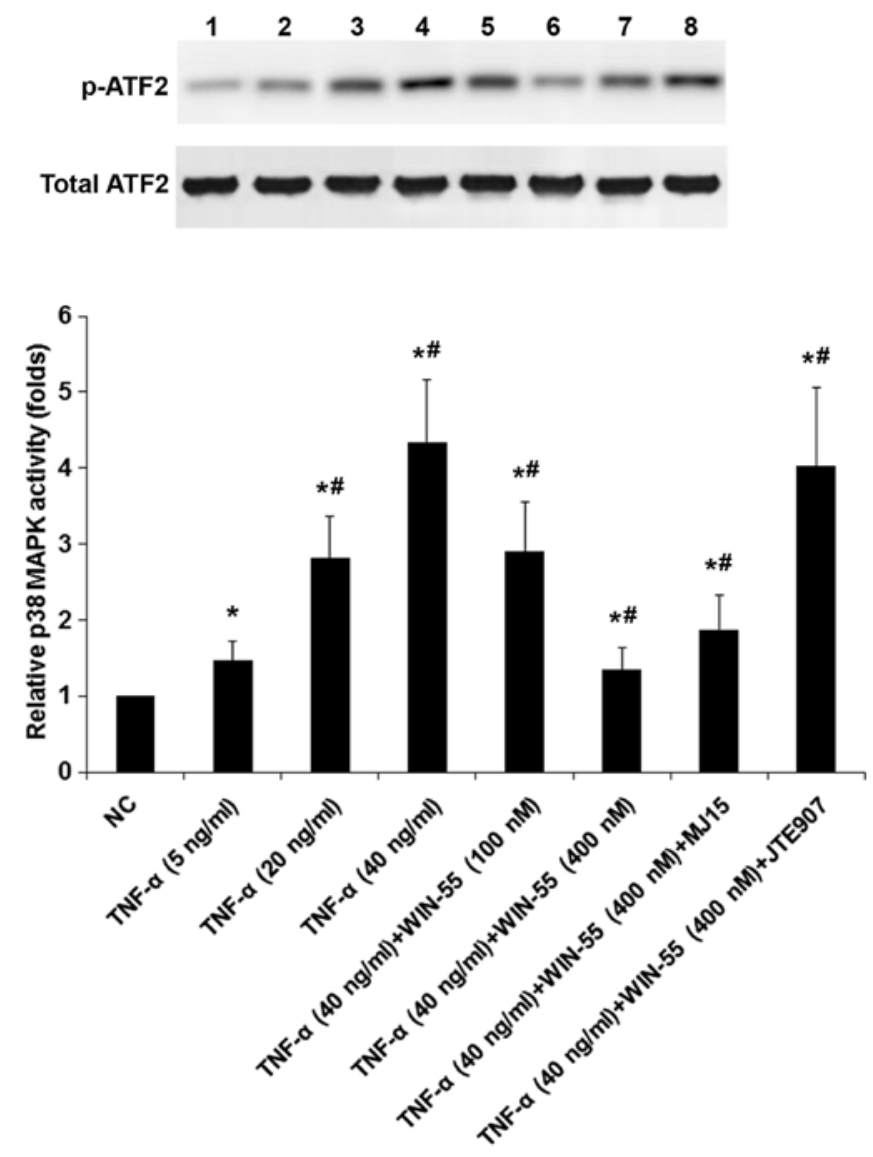

Figure 8. p38 MAPK activities in dorsal root ganglion (DRG) neurons under tumor necrosis factor- $\alpha$ (TNF- $\alpha$ ) treatment in the presence of synthetic cannabinoid WIN-55,212-2 mesylate (WIN-55) and cannabinoid receptor antagonists. DRG neurons were treated with TNF- $\alpha(5,20$ and $40 \mathrm{ng} / \mathrm{ml})$ in the presence of WIN-55 (100 or $400 \mathrm{ng} / \mathrm{ml})$ for $25 \mathrm{~h}$ with or without selective cannabinoid receptor type 1 (CB1) antagonist MJ15 (50 $\mu \mathrm{M})$ or selective CB2 antagonist JTE907 $(5 \mu \mathrm{M})$. Untreated cells (NC) were used as a control. The p38 MAPK activity was determined by measuring phosphorylation of ATF2, a substrate of activated p38 MAPK. The levels of phosphorylated ATF2 (p-ATF2) and total ATF2 (loaded equally at $2 \mu \mathrm{g}$ as a substrate in each sample) were determined with western blot analyses. The p-ATF2 level was normalized against that of total ATF2 to represent the p38 MAPK activity, which was shown as fold changes to that of NC (designated as 1). ${ }^{*} \mathrm{p}<0.05$ vs. control; ${ }^{\#} \mathrm{p}<0.05$ vs. immediate previous experimental group.

adds new insights into the pathophysiology of neuropathic pain and other chronic pains, e.g. inflammatory pain, in which TNF- $\alpha / \mathrm{p} 38$ MAPK/NOS signaling is very likely involved.

In conclusion, our findings suggest that TNF- $\alpha$ induces expression/activity of nNOS in DRG neurons by increasing its mRNA stability by a p38 MAPK-dependent mechanism; synthetic cannabinoid WIN-55 inhibits this effect of TNF- $\alpha$ by inhibiting p38 MAPK via CB2.

\section{Acknowledgements}

Not applicable.

\section{Funding}

This study was supported by the Hunan Provincial Natural Science Foundation (grants no. 2015A537), Changsha, Hunan, China. 


\section{Availability of data and material}

The datasets used and/or analyzed during the current study are available from the corresponding author on reasonable request.

\section{Authors' contributions}

RT participated in the study design, collected the data, carried out data analysis, and drafted the manuscript. LC participated in the study design, carried out data analysis, and performed data check and proofreading. All authors read and approved the final manuscript.

\section{Ethics approval and consent to participate}

Not applicable.

\section{Consent for publication}

Not applicable.

\section{Competing interests}

The authors declare that they have no competing interests.

\section{References}

1. Saarto T and Wiffen PJ: Antidepressants for neuropathic pain Cochrane Database Syst Rev 3: CD005454, 2005.

2. Lin HC, Huang YH, Chao TH, Lin WY, Sun WZ and Yen CT: Gabapentin reverses central hypersensitivity and suppresses medial prefrontal cortical glucose metabolism in rats with neuropathic pain. Mol Pain 10: 63, 2014.

3. Przewlocki R and Przewlocka B: Opioids in neuropathic pain. Curr Pharm Des 11: 3013-3025, 2005.

4. Chu LW, Chen JY, Wu PC and Wu BN: Atorvastatin prevents neuroinflammation in chronic constriction injury rats through nuclear NFkB downregulation in the dorsal root ganglion and spinal cord. ACS Chem Neurosci 6: 889-898, 2015.

5. Yang Y, Wu H, Yan JQ, Song ZB and Guo QL: Tumor necrosis factor- $\alpha$ inhibits angiotensin II receptor type 1 expression in dorsal root ganglion neurons via $\beta$-catenin signaling. Neuroscience 248: 383-391, 2013.

6. Westacott CI, Atkins RM, Dieppe PA and Elson CJ: Tumor necrosis factor-alpha receptor expression on chondrocytes isolated from human articular cartilage. J Rheumatol 21: 1710-1715, 1994

7. Boettger MK, Uceyler N, Zelenka M, Schmitt A, Reif A, Chen Y and Sommer C: Differences in inflammatory pain in nNOS-, iNOS- and eNOS-deficient mice. Eur J Pain 11: 810-818, 2007.

8. Tao F, Tao YX, Zhao C, Doré S, Liaw WJ, Raja SN and Johns RA: Differential roles of neuronal and endothelial nitric oxide synthases during carrageenan-induced inflammatory hyperalgesia. Neuroscience 128: 421-430, 2004.

9. Hama A and Sagen J: Antinociceptive effect of cannabinoid agonist WIN 55,212-2 in rats with a spinal cord injury. Exp Neurol 204: 454-457, 2007.

10. Rahn EJ and Hohmann AG: Cannabinoids as pharmacotherapies for neuropathic pain: From the bench to the bedside Neurotherapeutics 6: 713-737, 2009.

11. Hegyi Z, Kis G, Holló K, Ledent C and Antal M: Neuronal and glial localization of the cannabinoid-1 receptor in the superficial spinal dorsal horn of the rodent spinal cord. Eur J Neurosci 30: 251-262, 2009.
12. Hsieh GC, Pai M, Chandran P, Hooker BA, Zhu CZ, Salyers AK, Wensink EJ, Zhan C, Carroll WA, Dart MJ, et al: Central and peripheral sites of action for $\mathrm{CB} 2$ receptor mediated analgesic activity in chronic inflammatory and neuropathic pain models in rats. Br J Pharmacol 162: 428-440, 2011.

13. Lim G, Sung B, Ji RR and Mao J: Upregulation of spinal cannabinoid-1-receptors following nerve injury enhances the effects of Win 55,212-2 on neuropathic pain behaviors in rats. Pain 105 : 275-283, 2003.

14. Amaya F, Shimosato G, Kawasaki Y, Hashimoto S, Tanaka Y, Ji RR and Tanaka M: Induction of CB1 cannabinoid receptor by inflammation in primary afferent neurons facilitates antihyperalgesic effect of peripheral CB1 agonist. Pain 124: 175-183, 2006

15. Fernández-Ruiz J, Pazos MR, García-Arencibia M, Sagredo O and Ramos JA: Role of CB2 receptors in neuroprotective effects of cannabinoids. Mol Cell Endocrinol 286 (Suppl 1): S91-S96, 2008.

16. Mbvundula EC, Bunning RA and Rainsford KD: Arthritis and cannabinoids: HU-210 and Win-55,212-2 prevent IL-1alphainduced matrix degradation in bovine articular chondrocytes in-vitro. J Pharm Pharmacol 58: 351-358, 2006.

17. Liu Q, Bhat M, Bowen WD and Cheng J: Signaling pathways from cannabinoid receptor-1 activation to inhibition of $\mathrm{N}$-methyl-D-aspartic acid mediated calcium influx and neurotoxicity in dorsal root ganglion neurons. J Pharmacol Exp Ther 331: 1062-1070, 2009

18. Anand U, Otto WR, Sanchez-Herrera D, Facer P, Yiangou Y, Korchev Y, Birch R, Benham C, Bountra C, Chessell IP, et al: Cannabinoid receptor CB2 localisation and agonist-mediated inhibition of capsaicin responses in human sensory neurons. Pain 138: 667-680, 2008.

19. Paszcuk AF, Dutra RC, da Silva KA, Quintão NL, Campos MM and Calixto JB: Cannabinoid agonists inhibit neuropathic pain induced by brachial plexus avulsion in mice by affecting glial cells and MAP kinases. PLoS One 6: e24034, 2011.

20. Livak KJ and Schmittgen TD: Analysis of relative gene expression data using real-time quantitative PCR and the $2(-\Delta \Delta \mathrm{C}(\mathrm{T}))$ method. Methods 25: 402-408, 2001.

21. Wang $\mathrm{X}, \mathrm{Wu} \mathrm{H}$ and Miller AH: Interleukin 1alpha (IL-1alpha) induced activation of $\mathrm{p} 38$ mitogen-activated protein kinase inhibits glucocorticoid receptor function. Mol Psychiatry 9: 65-75, 2004.

22. Jia P, Wang J, Wang L, Chen X, Chen Y, Li WZ, Long R, Chen J, Shu YW, Liu K, et al: TNF- $\alpha$ upregulates Fgl2 expression in rat myocardial ischemia/reperfusion injury. Microcirculation 20: 524-533, 2013.

23. Wang RK, Zhang QQ, Pan YD and Guo QL: Etanercept decreases HMGB1 expression in dorsal root ganglion neuron cells in a rat chronic constriction injury model. Exp Ther Med 5: 581-585, 2013.

24. Xu JT, Xin WJ, Wei XH, Wu CY, Ge YX, Liu YL, Zang Y, Zhang T, Li YY and Liu XG: p38 activation in uninjured primary afferent neurons and in spinal microglia contributes to the development of neuropathic pain induced by selective motor fiber injury. Exp Neurol 204: 355-365, 2007.

25. Wilkerson JL, Gentry KR, Dengler EC, Wallace JA, Kerwin AA, Kuhn MN, Zvonok AM, Thakur GA, Makriyannis A and Milligan ED: Immunofluorescent spectral analysis reveals the intrathecal cannabinoid agonist, AM1241, produces spinal antiinflammatory cytokine responses in neuropathic rats exhibiting relief from allodynia. Brain Behav 2: 155-177, 2012

26. Wilkerson JL, Gentry KR, Dengler EC, Wallace JA, Kerwin AA, Armijo LM, Kuhn MN, Thakur GA, Makriyannis A and Milligan ED: Intrathecal cannabilactone $\mathrm{CB}(2) \mathrm{R}$ agonist, AM1710, controls pathological pain and restores basal cytokine levels. Pain 153: 1091-1106, 2012.

This work is licensed under a Creative Commons Attribution-NonCommercial-NoDerivatives 4.0 International (CC BY-NC-ND 4.0) License. 